\title{
Communication
}

\section{Searching for New Z-DNA/Z-RNA Binding Proteins Based on Structural Similarity to Experimentally Validated $Z \alpha$ Domain}

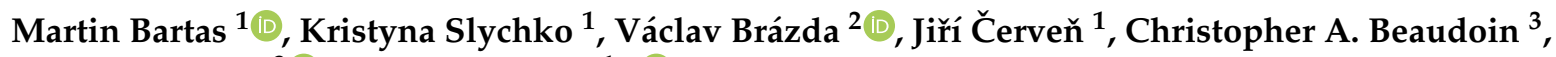 \\ Tom L. Blundell ${ }^{3}$ (D) and Petr Pečinka ${ }^{1, *(D)}$ \\ 1 Department of Biology and Ecology, Faculty of Science, University of Ostrava, \\ 71000 Ostrava, Czech Republic; martin.bartas@osu.cz (M.B.); P21097@student.osu.cz (K.S.); \\ jiri.cerven@osu.cz (J.Č.) \\ 2 Department of Biophysical Chemistry and Molecular Oncology, Institute of Biophysics of the Czech Academy \\ of Sciences, 61265 Brno, Czech Republic; vaclav@ibp.cz \\ 3 Department of Biochemistry, Sanger Building, University of Cambridge, Tennis Court Rd., \\ Cambridge CB2 1GA, UK; cab233@cam.ac.uk (C.A.B.); tlb20@cam.ac.uk (T.L.B.) \\ * Correspondence: petr.pecinka@osu.cz
}

Citation: Bartas, M.; Slychko, K.; Brázda, V.; Červeň, J.; Beaudoin, C.A.; Blundell, T.L.; Pečinka, P. Searching for New Z-DNA/Z-RNA Binding Proteins Based on Structural Similarity to Experimentally Validated $Z \propto \alpha$ Domain. Int. J. Mol. Sci. 2022, 23, 768. https://doi.org/ $10.3390 /$ ijms 23020768

Academic Editors: Maurizio Battino, Vaclav Brazda and Richard Bowater

Received: 30 November 2021

Accepted: 5 January 2022

Published: 11 January 2022

Publisher's Note: MDPI stays neutral with regard to jurisdictional claims in published maps and institutional affiliations.

Copyright: (C) 2022 by the authors. Licensee MDPI, Basel, Switzerland. This article is an open access article distributed under the terms and conditions of the Creative Commons Attribution (CC BY) license (https:// creativecommons.org/licenses/by/ $4.0 /)$.

\begin{abstract}
Z-DNA and Z-RNA are functionally important left-handed structures of nucleic acids, which play a significant role in several molecular and biological processes including DNA replication, gene expression regulation and viral nucleic acid sensing. Most proteins that have been proven to interact with Z-DNA/Z-RNA contain the so-called Z $\alpha$ domain, which is structurally well conserved. To date, only eight proteins with $Z \alpha$ domain have been described within a few organisms (including human, mouse, Danio rerio, Trypanosoma brucei and some viruses). Therefore, this paper aimed to search for new Z-DNA/Z-RNA binding proteins in the complete PDB structures database and from the AlphaFold 2 protein models. A structure-based similarity search found 14 proteins with highly similar $\mathrm{Z} \alpha$ domain structure in experimentally-defined proteins and 185 proteins with a putative $\mathrm{Z} \alpha$ domain using the AlphaFold 2 models. Structure-based alignment and molecular docking confirmed high functional conservation of amino acids involved in Z-DNA/Z-RNA, suggesting that Z-DNA/ZRNA recognition may play an important role in a variety of cellular processes.
\end{abstract}

Keywords: Z-DNA; Z-RNA; Z $\alpha$ domain; protein binding; bioinformatics

\section{Introduction}

Local DNA structures, also called 'non-B' DNA structures, have been recognised as important regulators of many fundamental regulatory processes, including replication [1], transcription [2], translation [3], epigenetics [4], DNA damage repair [5-7], genome evolution and rearrangement [8]. Negative supercoiling of DNA and protein binding can increase the stability of local DNA conformation and/or induce conformational changes that give rise to various alternative DNA structures, the best-described being cruciforms [7], Z-DNA/Z-RNA [9,10], triplexes [11] and quadruplexes [12]. Recently, a large number of proteins that recognise especially G-quadruplexes [13] and cruciforms [7,14] were characterised. Surprisingly, only a few Z-DNA/Z-RNA binding proteins have been characterised to date [15-23]. Z-DNA is a left-handed form of deoxyribonucleic acid, and its name was derived from the typical 'zig-zag' pattern (Figure 1). This DNA structure was first proposed by Robert Wells and his colleagues in 1970, during their physical and enzymatic studies on $\mathrm{d}(\mathrm{I}-\mathrm{C})$ polymers (consisting of altered inosine and cytosine units) [24]. The first structure of Z-DNA was subsequently solved by Andrew H. Wang et al. in 1979 using complementary hexamers of $\mathrm{d}(\mathrm{CG})_{3}$ [25]. The next development was the crystallographic structure of the so-called B-Z junction (DNA loci where right-handed B-DNA passes to a left-handed Z-DNA conformation, or vice versa) [26]. Many biochemical and biophysical in vitro experiments have been conducted to better characterise Z-DNA behaviour at close 
to physiological conditions $[27,28]$ and also to better understand switching between $B$ and Z-DNA [29,30]. Furthermore, several bioinformatic searches have been performed to predict Z-DNA-prone sequence motifs in the genomic DNA of some model organisms, including humans [31,32]. Z-DNA structures can be formed only in specific double-stranded sequences with alternating purine-pyrimidine tracks, which has been determined by crystallography in various nucleotide repeats, where specifically Z-DNA containing GC repeats have been shown to have increased stability [33]. These sequences with a high potential to form Z-DNA were observed in the genomes of organisms across all domains of life, and their particular importance has been shown: e.g., in transposable ALU elements [34], and gene promoters [35]. In 2009, the first human map of experimentally-obtained Z-DNA forming sites was released [36], followed by the ChIP-seq map in 2016, where they associated Z-DNA forming sites with actively transcribed regions in the human genome [37]. Since these discoveries, it is clear that Z-DNA structures arise under physiological conditions. However, compared to classical B-DNA conformations, Z-DNA structures are energetically unfavourable and, therefore, the structure formation requires energy (usually in the form of negative supercoiling), which results in less structural stability [38].

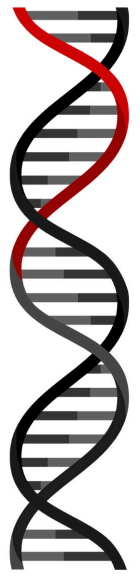

B-DNA

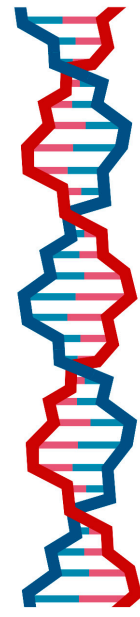

Z-DNA/Z-RNA

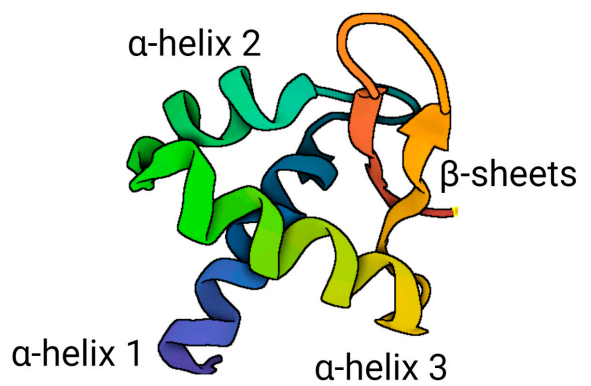

Za domain

Figure 1. Schematic diagram of classical right-handed B-DNA, left-handed Z-DNA/Z-RNA, and $\mathrm{Z} \alpha$ domain consisting of three $\alpha$-helices and two $\beta$-strands. This domain is known to specifically interact with left-handed nucleic acids, mainly through its $\alpha$-helix 3 and some amino acid residues of beta-strands.

In addition to Z-DNA, there is an analogous structure called Z-RNA (i.e., double-stranded left-handed RNA) that was firstly described in detail in 1984 by Kathleen Hall et al. [39]. Using a combination of spectroscopic techniques, they found that poly(GC).poly(GC) undergoes a transition from the classical A-form to a left-handed Z-form. Z-RNA has also been found in viral genomes, For example, the influenza virus has been shown to produce Z-RNA during replication, which can induce ZBP1-mediated necroptosis [40]. Additionally, SARS-CoV-2 has been reported to contain loci that theoretically form Z-RNAs (not published, analysed in house using the Non-B DB webserver [41]) [33-35,40,41].

It is assumed that Z-DNA/Z-RNA structures often need 'special' binding proteins for their stabilisation. Most known Z-DNA binding proteins bind to left-handed nucleic acids through the so-called Z-DNA binding domain Z $\alpha$ (Figure 1). One of the first discovered human Z-DNA binding proteins was double-stranded RNA adenosine deaminase (now designated as ADAR1) in 1995 by Herbert et al. [42]. The $Z \alpha$ domain was also discovered in DAI, PKZ, E3L, and ORF112 proteins [21], and a recent study found that this domain is present in RBP7910 protein [43]. The structure of the $Z \alpha$ domain has a specific $\beta$-sheet-helixturn-helix motif $(\beta \mathrm{HTH})$, which is a subgroup of the winged HTH motif $(\mathrm{wHTH})$. The Z $\alpha$ 
domain usually consists of three $\alpha$-helices and sheets of two or three $\beta$-strands $(\alpha \beta \alpha \alpha \beta \beta)$. The $\beta$-wing motif is formed by two antiparallel $\beta$-sheets composed of $\beta 2$ and $\beta 3$. The resulting $\beta$-wing and third $\alpha$-helix play an important role in recognition and binding to Z-DNA $[21,44]$.

During the past 40 years of research, only about ten Z-DNA (or Z-RNA) binding proteins have been identified in different organisms. All known Z-DNA/Z-RNA proteins that contain $Z \alpha$ domains have been demonstrated to be involved in the immune response (ADAR1, ZBP1, PKZ) [19,45-48] and/or virus-host interactions (E3L protein from Vaccinia virus, ORF112 protein from Cyprinid herpesvirus 3) [21,49-51]. Some studies have also shown that the binding of the $Z \alpha$ domain to Z-RNA is responsible for the localisation of Z-DNA/Z-RNA binding proteins into cytoplasmic stress granules [52-54]. One of the most well-characterised Z-DNA/Z-DNA binding proteins, ADAR 1, is, in fact, a moonlighting protein [55], and its Z-DNA/Z-RNA binding function was discovered [56] after it was originally described as an adenosine deaminase [57]. This led us to the hypothesis that some functionally characterised proteins may still possess an unidentified Z-DNA/Z-RNA binding function. Therefore, this paper aims to identify new Z-DNA/RNA binding proteins based on structural similarity to an experimentally well-defined $\mathrm{Z} \alpha$ domain.

\section{Results and Discussion}

2.1. Prediction of New Z-DNA/Z-RNA Binding Proteins Based on Structural Similarity to the Experimentally Validated $\mathrm{Z} \alpha$ Domain

At the beginning of our study, we made a list of experimentally solved $Z \alpha$ (and $Z \beta$ ) domain structures (Table 1). After careful consideration (based mainly on the atomicresolution and selection of a well-characterised human protein), we chose the crystal structure of the $Z \alpha$ domain from the human protein ADAR1 in complex with non-CGrepeat Z-DNA, obtained by Sung Chul Ha et al. in 2009 at a resolution of $2.20 \AA$ [58]. Using this experimental $Z \alpha$ domain structure (PDB: 3f21, chain A), we carried out structural similarity searches using the PDBeFold web server (https:/ / www.ebi.ac.uk/msd-srv/ssm/, (accessed on 10 September 2021)) and RUPEE web server (https:/ / ayoubresearch.com/, (accessed on 21 October 2021)). The PDBeFold algorithm allows examination of a given protein structure for similarity with the whole PDB archive containing nearly 200k of experimentally solved protein structures from a variety of model and nonmodel organisms, whereas RUPEE allows the querying of protein structures predicted by AlphaFold2 [59].

Table 1. Known Z-DNA/RNA binding proteins containing experimentally solved Z $\alpha$ or Z $\beta$ domain(s) (PDB IDs are provided). UniProtKB IDs of all proteins are provided as well.

\begin{tabular}{|c|c|c|c|c|c|c|c|c|}
\hline $\begin{array}{c}\text { Protein } \\
\text { Symbol/ID }\end{array}$ & Protein Name & Organism & $\begin{array}{l}\text { Protein } \\
\text { Length }\end{array}$ & Function & $\begin{array}{l}\text { PDB } \\
\text { ID }\end{array}$ & $\begin{array}{c}\text { Method/ } \\
\text { Resolution }\end{array}$ & Domain & Ref. \\
\hline \multirow{6}{*}{$\begin{array}{l}\text { ADAR } \\
(\mathrm{P} 55265)\end{array}$} & \multirow{6}{*}{$\begin{array}{l}\text { Double-stranded } \\
\text { RNA-specific } \\
\text { adenosine } \\
\text { deaminase }\end{array}$} & \multirow{6}{*}{ Homo sapiens } & \multirow{6}{*}{1226} & \multirow{6}{*}{$\begin{array}{c}\text { Hydrolytic } \\
\text { deamination of } \\
\text { adenosine to inosine } \\
\text { in dsRNA (A-to-I } \\
\text { RNA editing) }\end{array}$} & 1XMK & $\mathrm{XRC} / 0.97 \AA$ & $\mathrm{Z} \beta$ & [60] \\
\hline & & & & & 1QGP & NMR & $\mathrm{Z} \alpha$ & [61] \\
\hline & & & & & $3 F 21$ & $\mathrm{XRC} / 2.20 \AA$ & $Z \alpha$ & \multirow{3}{*}{ [58] } \\
\hline & & & & & $3 F 22$ & $\mathrm{XRC} / 2.50 \AA$ & $\mathrm{Z} \alpha$ & \\
\hline & & & & & $3 F 23$ & $\mathrm{XRC} / 2.70 \AA$ & $Z \alpha$ & \\
\hline & & & & & $2 \mathrm{GXB}$ & $\mathrm{XRC} / 2.25 \AA$ & $\mathrm{Z} \alpha$ & [16] \\
\hline $\begin{array}{c}\text { ZBP1 } \\
(\mathrm{Q} 9 \mathrm{H} 171)\end{array}$ & $\begin{array}{l}\text { Z-DNA-binding } \\
\text { protein } 1\end{array}$ & Homo sapiens & 429 & \multirow{2}{*}{$\begin{array}{l}\text { Innate sensor } \\
\text { recognising viral } \\
\text { Z-RNA }\end{array}$} & $2 \mathrm{~L} 4 \mathrm{M}$ & NMR & $\mathrm{Z} \beta$ & [62] \\
\hline Zbp1/DAI & $\begin{array}{l}\text { Z-DNA-binding } \\
\text { protein } 1\end{array}$ & Mus musculus & 411 & & $1 J 75$ & $\mathrm{XRC} / 1.85 \AA$ & $\mathrm{Z} \alpha$ & [18] \\
\hline
\end{tabular}


Table 1. Cont.

\begin{tabular}{|c|c|c|c|c|c|c|c|c|}
\hline $\begin{array}{c}\text { Protein } \\
\text { Symbol/ID }\end{array}$ & Protein Name & Organism & $\begin{array}{l}\text { Protein } \\
\text { Length }\end{array}$ & Function & $\begin{array}{l}\text { PDB } \\
\text { ID }\end{array}$ & $\begin{array}{l}\text { Method/ } \\
\text { Resolution }\end{array}$ & Domain & Ref. \\
\hline \multirow{2}{*}{$\begin{array}{c}\text { PKZ } \\
(\mathrm{Q} 5 \mathrm{NE12})\end{array}$} & \multirow{2}{*}{$\begin{array}{l}\text { Protein kinase- } \\
\text { containing } \\
\text { Z-DNA-binding } \\
\text { domains }\end{array}$} & \multirow{2}{*}{ Danio rerio } & \multirow[t]{2}{*}{511} & \multirow{2}{*}{$\begin{array}{c}\text { Defence response to } \\
\text { virus }\end{array}$} & 4LB5 & $\mathrm{XRC} / 2.00 \AA$ & \multirow{2}{*}{$\mathrm{Z} \alpha$} & \multirow{2}{*}{ [20] } \\
\hline & & & & & $4 \mathrm{LB} 6$ & $\mathrm{XRC} / 1.80 \AA$ & & \\
\hline $\begin{array}{l}\text { ORF112 } \\
\text { (A4FTK7) }\end{array}$ & Protein ORF112 & $\begin{array}{c}\text { Cyprinid } \\
\text { herpesvirus } 3\end{array}$ & 278 & $\begin{array}{l}\text { Double-stranded } \\
\text { RNA adenosine } \\
\text { deaminase activity; } \\
\text { RNA binding }\end{array}$ & 4WCG & XRC $/ 1.50 \AA$ & $\mathrm{Z} \alpha$ & [21] \\
\hline $\begin{array}{c}\text { E3L } \\
(\mathrm{P} 21605)\end{array}$ & Protein E3 & Vaccinia virus & 190 & $\begin{array}{c}\text { Double-stranded } \\
\text { RNA adenosine } \\
\text { deaminase activity; } \\
\text { inhibition of } \\
\text { multiple cellular } \\
\text { antiviral responses } \\
\text { activated by dsRNA }\end{array}$ & 7COI & XRC $/ 2.40 \AA$ & $\mathrm{Z} \alpha$ & [63] \\
\hline $\begin{array}{c}34 \mathrm{~L} \\
\text { (Q9DHS8) }\end{array}$ & 34L protein & $\begin{array}{c}\text { Yaba-like } \\
\text { disease virus }\end{array}$ & 185 & Same as E3L & 1SFU & XRC/2.00 & $\mathrm{Z} \alpha$ & [22] \\
\hline
\end{tabular}

In Table 2, all non-redundant hits with a Q-score higher than a predefined threshold are shown. The $Q$-score represents the quality function of the $C \alpha$ alignment, maximised by the secondary structure matching (SSM) alignment algorithm [64]. The Q-score is reported in an interval from 0 to 1 , where the Q-score reaches 1 in the case of identical structures and decreases with an increasing RMSD or a smaller alignment length. A Q-score of 0 indicates completely dissimilar structures. A Q-score higher than 0.1 can indicate some possibly significant level of structural similarity. Nonetheless, in this research, we set a more stringent $Q$-score threshold of 0.55 . This value seemed to be meaningful as there were known structures of Z-DNA/Z-RNA binding proteins that scored below the newly reported domains (i.e., structures where the Z-DNA/Z-RNA binding function has not been described so far).

Table 2. Predicted Z-DNA/RNA binding proteins based on structural similarity to the experimentally validated $Z \alpha$ domain (3f21). Proteins are sorted according to their decreasing similarity score (Qscore); HOP2 is the best hit. UniProtKB IDs of all proteins are provided as well.

\begin{tabular}{|c|c|c|c|c|c|}
\hline $\begin{array}{c}\text { Protein } \\
\text { Symbol/ID }\end{array}$ & Protein Name & Organism & Domain & $\begin{array}{l}\text { Protein } \\
\text { Length }\end{array}$ & $\begin{array}{l}\text { Cellular Localisation/Known } \\
\text { Function }\end{array}$ \\
\hline HOP2 (O35047) & $\begin{array}{l}\text { Homologous-pairing } \\
\text { protein } 2 \text { homolog }\end{array}$ & Mus musculus & Eukarya & 217 & $\begin{array}{c}\text { Nucleus/DNA binding, meiotic } \\
\text { recombination, double-strand } \\
\text { break repair, positive regulation } \\
\text { of transcription by RNA pol II } \\
{[65,66]}\end{array}$ \\
\hline DsvD (Q46582) & DsvD & $\begin{array}{l}\text { Desulfovibrio } \\
\text { vulgaris }\end{array}$ & Bacteria & 78 & $\begin{array}{l}\text { Role in dissimilatory sulfite } \\
\text { reduction, Possible Interaction } \\
\text { with B- and Z-DNA by Its } \\
\text { Winged-Helix Motif [67] }\end{array}$ \\
\hline D2PEW5 & $\begin{array}{l}\text { Uncharacterised DNA } \\
\text { binding protein }\end{array}$ & $\begin{array}{l}\text { Sulfolobus } \\
\text { islandicus }\end{array}$ & Archaea & 59 & DNA binding \\
\hline $\begin{array}{c}\text { feoC } \\
(\mathrm{B} 5 X \mathrm{XT} 6)\end{array}$ & $\begin{array}{l}\text { Probable [Fe-S]-dependent } \\
\text { transcriptional repressor }\end{array}$ & $\begin{array}{l}\text { Klebsiella } \\
\text { pneumoniae }\end{array}$ & Bacteria & 79 & $\begin{array}{l}\text { DNA binding may function as a } \\
\text { transcriptional regulator that } \\
\text { controls feoABC expression [68] }\end{array}$ \\
\hline
\end{tabular}


Table 2. Cont.

\begin{tabular}{|c|c|c|c|c|c|}
\hline $\begin{array}{c}\text { Protein } \\
\text { Symbol/ID }\end{array}$ & Protein Name & Organism & Domain & $\begin{array}{l}\text { Protein } \\
\text { Length }\end{array}$ & $\begin{array}{l}\text { Cellular Localisation/Known } \\
\text { Function }\end{array}$ \\
\hline $\begin{array}{c}\text { pefI } \\
(\mathrm{Q} 04822)\end{array}$ & FaeA-like protein & $\begin{array}{l}\text { Salmonella } \\
\text { typhimurium }\end{array}$ & Bacteria & 70 & Regulation of transcription [69] \\
\hline RPA2 (P15927) & $\begin{array}{l}\text { Replication protein A } 32 \\
\text { kDa subunit }\end{array}$ & Homo sapiens & Eukarya & 270 & $\begin{array}{l}\text { Nucleus/DNA binding, } \\
\text { multifunctional protein (DNA } \\
\text { repairs, DNA replication, } \\
\text { telomere maintenance, } \\
\text { preventing G-quadruplex } \\
\text { formation) [70-73] }\end{array}$ \\
\hline CDC53 (Q12018) & $\begin{array}{l}\text { Cell division control protein } \\
\qquad 53\end{array}$ & $\begin{array}{l}\text { Saccharomyces } \\
\text { cerevisiae }\end{array}$ & Eukarya & 815 & $\begin{array}{c}\text { Nucleus \& Cytoplasm/DNA } \\
\text { replication origin binding, cell } \\
\text { division, protein ubiquitination } \\
{[74]}\end{array}$ \\
\hline CUL1 (Q13616) & Cullin-1 & Homo sapiens & Eukarya & 776 & $\begin{array}{l}\text { Nucleus \& Cytoplasm/Protein } \\
\text { ubiquitination, cell division, } \\
\text { transcription regulation [75] }\end{array}$ \\
\hline ANC2 (Q9UJX6) & $\begin{array}{l}\text { Anaphase-promoting } \\
\text { complex subunit } 2\end{array}$ & Homo sapiens & Eukarya & 822 & $\begin{array}{c}\text { Nucleus \& } \\
\text { Cytoplasm/Component of the } \\
\text { anaphase promoting } \\
\text { complex/cyclosome (APC/C) } \\
{[76]}\end{array}$ \\
\hline SCC1 (Q12158) & $\begin{array}{l}\text { Sister chromatid cohesion } \\
\text { protein } 1\end{array}$ & $\begin{array}{l}\text { Saccharomyces } \\
\text { cerevisiae }\end{array}$ & Eukarya & 566 & $\begin{array}{c}\text { Nucleus/Mitotic sister } \\
\text { chromatid cohesion, } \\
\text { double-strand break repair [77] }\end{array}$ \\
\hline APC2 (Q12440) & $\begin{array}{l}\text { Anaphase-promoting } \\
\text { complex subunit } 2\end{array}$ & $\begin{array}{l}\text { Saccharomyces } \\
\text { cerevisiae }\end{array}$ & Eukarya & 853 & $\begin{array}{c}\text { Nucleus \& } \\
\text { cytoplasm/Component of the } \\
\text { anaphase promoting } \\
\text { complex/cyclosome (APC/C) } \\
{[78]}\end{array}$ \\
\hline Rpc34 (Q921X6) & $\begin{array}{l}\text { DNA-directed RNA } \\
\text { polymerase III subunit } \\
\text { RPC6 }\end{array}$ & Mus musculus & Eukarya & 316 & $\begin{array}{l}\text { Nucleus/Nuclear and cytosolic } \\
\text { DNA sensor involved in innate } \\
\text { immune response, defence } \\
\text { response to the virus [79] }\end{array}$ \\
\hline $\begin{array}{c}\text { PBP2 } \\
\text { (A0A0E3GTJ4) }\end{array}$ & $\begin{array}{l}\text { Archaeal DNA polymerase } \\
\text { holoenzyme (PBP2 subunit) }\end{array}$ & $\begin{array}{l}\text { Saccharolobus } \\
\text { solfataricus }\end{array}$ & Archaea & 76 & Enhances DNA synthesis [80] \\
\hline $\begin{array}{l}\text { Reut_B4095 } \\
\text { (Q46TT3) }\end{array}$ & $\begin{array}{l}\text { Putative DNA-binding } \\
\text { protein }\end{array}$ & $\begin{array}{l}\text { Cupriavidus } \\
\text { pinatubonensis }\end{array}$ & Bacteria & 95 & DNA binding \\
\hline
\end{tabular}

The resulting hits from Table 2 are visualised in Figure 2, together with the "reference" structure of a Z $\alpha$ domain (PDB: 3f21), which was used as the query protein for the structural similarity searching. All 14 proteins show noticeable structural similarity to the functional $Z \alpha$ domain, as each of these structures contains three alpha-helices and two antiparallel beta-strands, in order, typical for the $Z \alpha$ domain. 


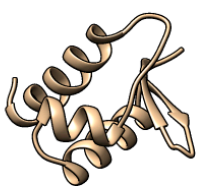

REFERENCE Z alpha (3f21:A)

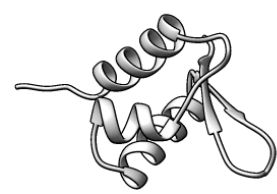

Pefl
$(2 j t 1: A)$

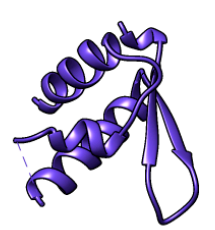

SCC1 (1w1w:H)
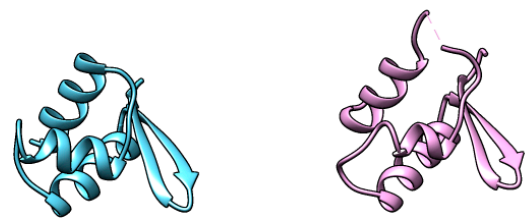

HOP2

(2mh2:A)

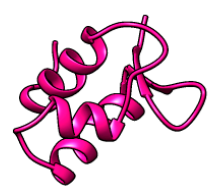

RPA2

(40u0:A)

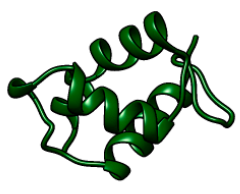

APC2

(1ldd:C)
DsvD

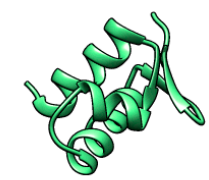

Uncharacterized (7bzh:A)

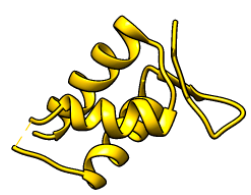

CDC53

(3o6b:D)

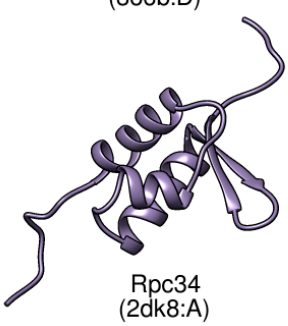

CUL1

(5v89:C)

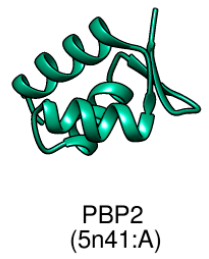

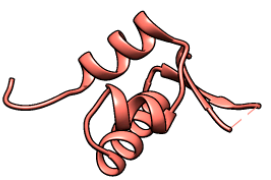

feoC

(4awx:B)

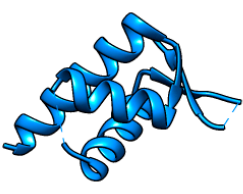

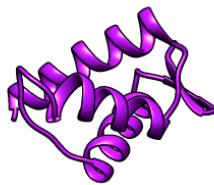

ANC2

(4yii:A)

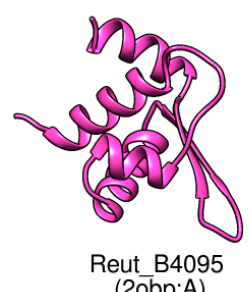

(2obp:A)

Figure 2. Comparison of the reference $\mathrm{Z} \alpha$ domain (PDB: 3f21) (upper left corner) with the experimentally solved proteins (or their corresponding domains) having significant structural similarity (structures are ordered according to their similarity score to the reference structure (HOP2 best, DsvD second best, etc.).

The best new possible Z-DNA/Z-RNA binding protein found (based on the highest Q-score of its $Z \alpha$ domain), homologous-pairing protein 2 (HOP2), is widely conserved across the whole Eukarya domain. HOP2 proteins play an important role in meiotic recombination, particularly that of stimulating DMC1-mediated strand exchange that is necessary for homologous chromosome pairing during meiosis [81]. HOP2 forms a heterodimeric complex together with Meiotic nuclear division protein 1 homolog (MND1), and this HOP2/MND1 complex also promotes DMC1 mediated D-loop formation from double-strand DNA. Interestingly, a short 3bp deletion in the gene encoding HOP2 protein (leading to a deletion of a glutamic acid residue in the highly conserved C-terminal acidic domain) in humans causes "XX female gonadal dysgenesis" (XX-GD), which is a rare genetic disorder characterised for example by primary amenorrhea, uterine hypoplasia, or hypergonadotropic hypogonadism [82]. Another four proteins share a Cullin domain, particularly CDC53, CUL1, ANC2, and APC2. Proteins CDC53 (from Saccharomyces cerevisiae) and CUL1 (from Homo sapiens) are very distant functional homologs, and the same for ANC2 (from Homo sapiens) and APC2 (from Saccharomyces cerevisiae). Regarding Cullin domains and related ubiquitination processes, there are interesting links to viral diseases, see e.g., Rudnicka et al. [83]. Considering the current SARS-CoV-2 pandemic, it would be interesting to validate the potential of the viral RNA to form Z-RNA structures during replication, as was described for the influenza virus (H1N1 strain Puerto Rico/8/1934) virus in 2020 [40]. In this article, Zhang et al. found that replicating influenza A virus produces Z-RNAs and these are sensed by host ZBP1 in the nucleus of the host cell. This process led to the activation of specific protein kinases, resulting in nuclear rupture and unwanted necroptosis. From our newly described Z-DNA/Z-RNA binding proteins, protein Rpc34, which is subunit 6 of human RNA polymerase III, seems to have a direct association with a viral infection. For example, identical twins having a mutation in POLR3F (gene encoding Rpc34) had different susceptibility to the varicella-zoster virus in the CNS and lungs - 
the patient with the POLR3F mutation exhibited impaired antiviral and inflammatory responses and increased viral replication [84].

Figure 3 shows a sequence alignment derived from the structural superposition of the predicted $Z \alpha$ domains from the analysed proteins to the $Z \alpha$ domain of the human protein ADAR1. All three alpha-helices are structurally conserved in the 14 possible Z-DNA/ZRNA binding proteins. Similarly, beta-sheets of two or three strands are mostly preserved, except for in protein APC2. Interestingly, some amino acids in the predicted $\mathrm{Z} \alpha$ domains were found to be repeatedly enriched in the exact positions of alignment-mainly in alpha helix 3, which is believed to be critical for Z-DNA/Z-RNA binding [52,60,85].

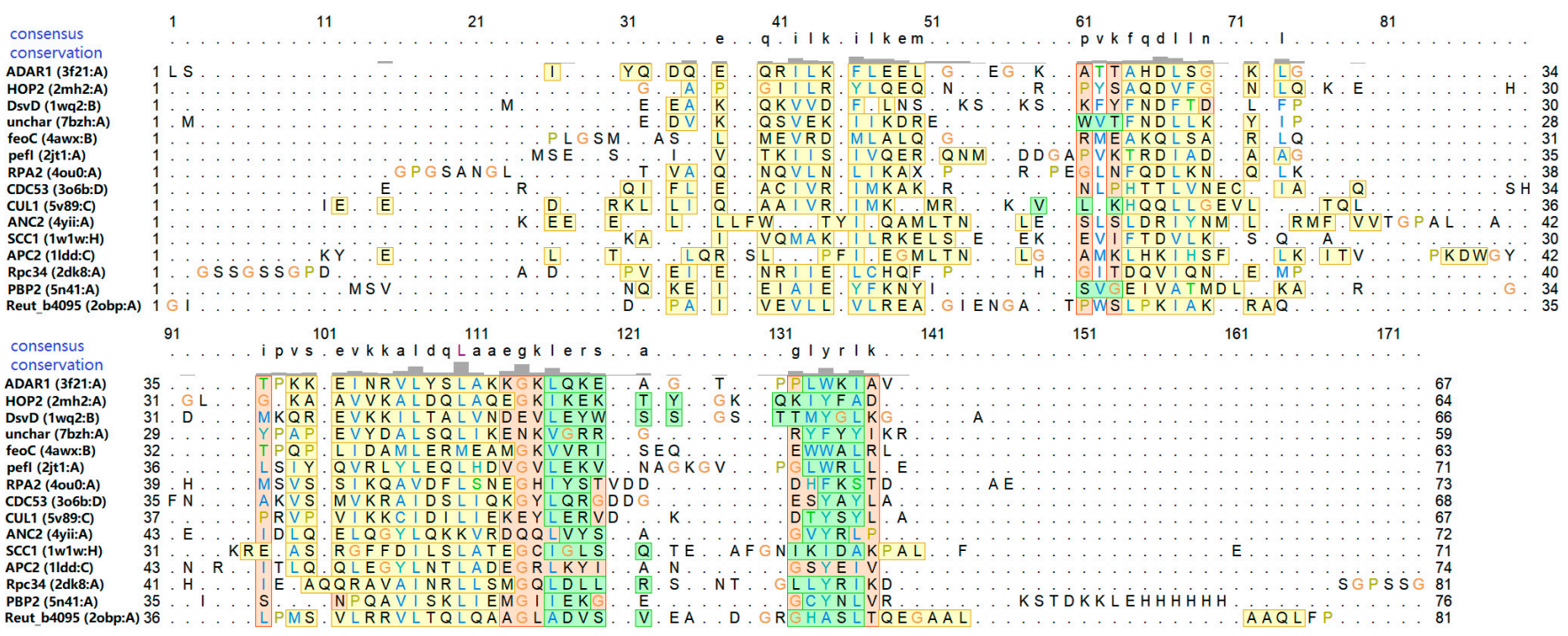

Figure 3. Sequence alignment is constructed from the structural superposition of the Z $\alpha$ domain of human ADAR1 protein (PDB: 3f21) and the 14 possible Z-DNA/Z-RNA binding proteins. The default colour of fully populated columns is light red, in addition, helices are coloured in yellow and strands in green. Letter colours correspond to the ClustalX colouring scheme.

Most of these 14 proteins identified (except for proteins CDC53 and CUL1, and proteins ANC2 and APC2) do not likely share a common evolutionary ancestor. Instead, the similar global fold of $Z \alpha$ 'domain' could be a result of convergent evolution [86,87] leading to preferential Z-DNA/Z-RNA structures binding. Currently known Z-DNA/Z-RNA binding proteins (ADAR, ZBP1, PKZ, E3L) are also not homologous, but rather analogous in their Z-DNA/Z-RNA binding function. This phenomenon is common in the case of other proteins which preferentially bind noncanonical forms of nucleic acids, such as G-quadruplex binding proteins [88] or cruciform binding proteins [89] (most of them don't have a common ancestor, but are analogous in their preferential interaction with Gquadruplexes, cruciforms, or another nucleic acid structures). In addition, it was found that some of the three-dimensional protein structures are widely conserved in non-homologous or unrelated DNA-binding proteins [90]. Then, the question arises we to whether the $\mathrm{Z} \alpha$ domain is correctly annotated as a protein family (pfam ID: PF02295) as protein families are usually defined as groups of evolutionarily (not necessary functionally) related proteins. According to information deposited in the Pfam database, the HMM profile of this protein family was defined using only 5 seeds (regions 135-201 and 295-359 of human protein ADAR, region 137-203 of ADAR protein from Rattus norvegicus, region 7-71 of protein E3L from Vaccinia virus, and region 1-64 of protein ORF020 dsRNA-binding PKR inhibitor from Orf virus (Q6TVV0_ORFSA). This selection is problematic, as 3 of the 5 seed regions come from human and rat protein ADAR. The average length of the $\mathrm{Z} \alpha$ domain is then 64.20 aa, with only $32 \%$ alignment identity. Therefore, we are sceptical about the current definition of the $Z \alpha$ domain on the level of the primary amino acid sequence. Nonetheless, further demystifying this issue is one motivation behind the scope of this paper, so we 
will continue with using the term ' $Z \alpha$ domain', in the sensu lato meaning, as the protein domain which preferentially interacts with Z-DNA/Z-RNA.

As the AlphaFold2 database [59] has provided putative structural models for thousands of proteins in several model organisms that have not yet been experimentally resolved, we sought to better understand which of these proteins may be involved in Z-DNA/Z-RNA binding. The ADAR1 Z $\alpha$ domain (PDB: 3f21) was chosen as a query structure for structural similarity searches using the RUPEE web server, which allows for the structural comparison with all AlphaFold2 models. RUPEE uses the TM-score to rank and quantify the structural similarity between protein alignments. On a scale from 0 to 1 , a TM-score of over 0.5 is predicted to imply a similar fold. In a similar manner to the high Q-score threshold value used with PDBeFold, a TM-score of over 0.6 was chosen as a basis for the selection of hits from the structural alignment screen with RUPEE [91]. Since many of the proteins in the AlphaFold2 database do not yet have functional annotations, structural comparisons may further delineate their roles in cell survival.

Using the ADAR1 Z $\alpha$ domain (PDB: 3f21) as the query protein for the RUPEE web server, a total of 308 proteins were returned. Subsequent manual inspection of the alignments was performed to ensure that the putative $\mathrm{Z} \alpha$ domains were structurally accessible and consisted primarily of basic residues that may be important for DNA-binding. A total of 185 unique proteins were selected after inspection, among which 59 proteins currently do not have complete functional annotation. Taking into consideration the previously annotated proteins that were predicted to contain one or more Z $\alpha$ domains, most have been assigned as putative transcriptional regulators-which further supports their potential to bind Z-DNA/Z-RNA. The probable [Fe-S]-dependent transcriptional repressor from Escherichia coli detected using RUPEE reflects the identification of the feoC protein from Klebsiella pneumoniae, detected using PDBeFold, that has been assigned the same function, which further validates the use of both structural comparison tools. In addition to feoC, additional similar proteins to Rpc34 and SCC1 were found, particularly DNA-directed RNA polymerase III subunit RPC3 (RNA polymerase III subunit C3) from Leishmania infantum and Rad21_Rec8 domain-containing protein from Glycine max. Interestingly, the uncharacterised proteins predicted to contain $Z \alpha$ domains were primarily found in the Drosophila melanogaster, Methanocaldococcus jannaschii, Staphylococcus aureus, and Mycobacterium tuberculosis proteomes (covering all three domains of life-Bacteria, Archaea, and Eukarya) The presence of proteins likely interacting with Z-DNA/Z-RNA in all domains of life further highlights the widespread occurrence of Z-DNA/Z-RNA and biological significance of such nucleic acid structures. The most numerous groups were uncharacterised proteins (59), transcriptional factors (56), and proteins related to ribosome biogenesis (49)-for further details see Supplementary Material S1. Both transcriptional factors and ribosomal proteins identified are in direct contact with DNA or RNA respectively, therefore their putative Z-DNA/Z-RNA binding ability is supported. The relatively large number of detected proteins, especially previously uncharacterised proteins, suggests that Z-DNA/Z-RNA binding domains may be more common than previously assumed. Further structural investigations may reveal the ability or extent of these proteins to bind ZDNA/Z-RNA. Nonetheless, as the reliability of AlphaFold2 structural predictions still have some shortcomings [92], we have further proceeded only with 14 possible Z-DNA/Z-RNA binding proteins obtained from PDBeFold searches (experimentally solved structures).

\subsection{Domain Composition and Nuclear Localisation Signals within the Most Promising Z-DNA/Z-RNA Binding Proteins}

Figure 4 shows the position of regions that are structurally similar to the $Z \alpha$ domain of ADAR1 and the 14 possible Z-DNA/RNA binding proteins inferred in the PDBeFold search (Table 2 and Figure 2). Interestingly, these regions are exclusively located in the N' (HOP2, Rpc34) or $C^{\prime}$ terminal ends (RPA2, CDC53, CUL1, ANC2, SCC1, APC2) of proteins longer than 100 aa. These data are in congruence with a previous observation by Chiang et al. [43], where they depicted the position of $Z \alpha$ domains in six proteins with known Z-DNA/RNA 
function ( $\mathrm{Z} \alpha$ domains were always located at the $\mathrm{N}$ terminal end of longer proteins). These results potentially highlight the need for maximal exposure of the $Z \alpha$ domain to be able to interact with this type of non-canonical nucleic acid structure. AlphaFold structures of predicted Z-DNA/Z-RNA binding proteins from Homo sapiens are enclosed in Supplementary Material S2, together with highlighted domains with structural similarity to $Z \alpha$. In addition, in protein HOP2, there is an isoform lacking the N-terminal region $(\Delta N)$ spanning the $\mathrm{Z} \alpha$ domain structural homolog. In the study conducted by Uanschou et al. they found that the $\mathrm{N}^{\prime}$ terminal domain of the protein HOP2 is crucial for its DNA-binding function in Arabidopsis thaliana [93]. Nevertheless, HOP2 protein seems to be highly conserved across Eukaryotic organisms (typical N-terminal wHTH was predicted also in the mouse, rat, human, Saccharomyces cerevisiae and Dictyostelium discoideum proteomes according to models obtained from AlphaFold2 database-https:/ / alphafold.ebi.ac.uk/search/text/hop2, (accessed on 25 October 2021)) [59]. The above-mentioned $\Delta \mathrm{N}$ isoform is also present in the human proteome according to UniProt Sequence annotation (Isoform 3: Q9P2W1-3, aa residues 1-125 are missing). Finally, there are also two previously known examples of human proteins ADAR1 and DAI, where, in both cases, $\Delta \mathrm{N}$ isoforms exist (which result in missing Z $\alpha$ domain). Regarding protein ADAR1, its short isoform ADAR1p110 is constitutively expressed and located in the nucleus, whereas the long isoform ADAR1p150 is interferon-inducible and undergoes shuffling between the cytoplasm and nucleus [94,95]. Both of these isoforms share a Z $\beta$ domain (which may not have Z-DNA-binding ability [60] and its function is still unknown [96]), A-to-I deaminase domain, three double-stranded RNA-binding domains, but the long P150 isoform has an extra Z-DNA/RNA-binding domain at its N-terminus [97].

All eukaryotic proteins found have at least theoretical possibility to be localised both in the cytoplasm and cell nucleus, as was checked in a literature search and using nuclear localisation signal prediction within primary amino acid sequences of these proteins (cNLS Mapper webserver, accessed from http:/ / nls-mapper.iab.keio.ac.jp/cgi-bin/NLS_Mapper_ form.cgi, (accessed on 11 November 2021)) [98] (Supplementary Material S3). It is worth mentioning that the overall amino acid composition of these fourteen proteins identified shows similar significant enrichments (isoleucine, lysine, aspartic acid) and depletion (cysteine) as observed previously by us [99].

\subsection{Representative Molecular Docking of RPA2 Region Structurally Similar to Z $\alpha$ Domain and Z-DNA/Z-RNA}

We carried out representative molecular docking (using theHDOCK web server [100], further details in Materials and Methods section) of the human RPA2 putative Z-DNA/ZRNA binding domain to Z-DNA (Figure 5A) and Z-RNA (Figure 5B). RPA2 was selected for its important molecular function in DNA replication and the cellular response to DNA damage. Results of this analysis revealed key amino acid residues involved in ZDNA and/or Z-RNA binding. In both cases, tyrosine at position 256 (considering the whole RPA2 protein) was involved, suggesting its critical role in interaction with lefthanded nucleic acids. In both cases, alpha-helix 3 and two subsequent beta-sheets seem to play pivotal roles in Z-DNA/Z-RNA recognition. These results are in congruence with previous experimental models of known Z $\alpha$ domains interacting with Z-DNA/Z-RNA, where the tyrosine, lysine, asparagine and serine amino acid residues played key roles in interaction $[21,52,101,102]$. The dockings of the remaining 13 possible Z-DNA/Z-RNA binding proteins are enclosed in Supplementary Material S4 (10 best docking poses for all protein/nucleic acid combinations). The inspection of the best docking poses revealed that it in general follows the rules described above. Carrying out a detailed molecular dynamic study would be beneficial in subsequent research to shed more light on the stability of these complexes. 


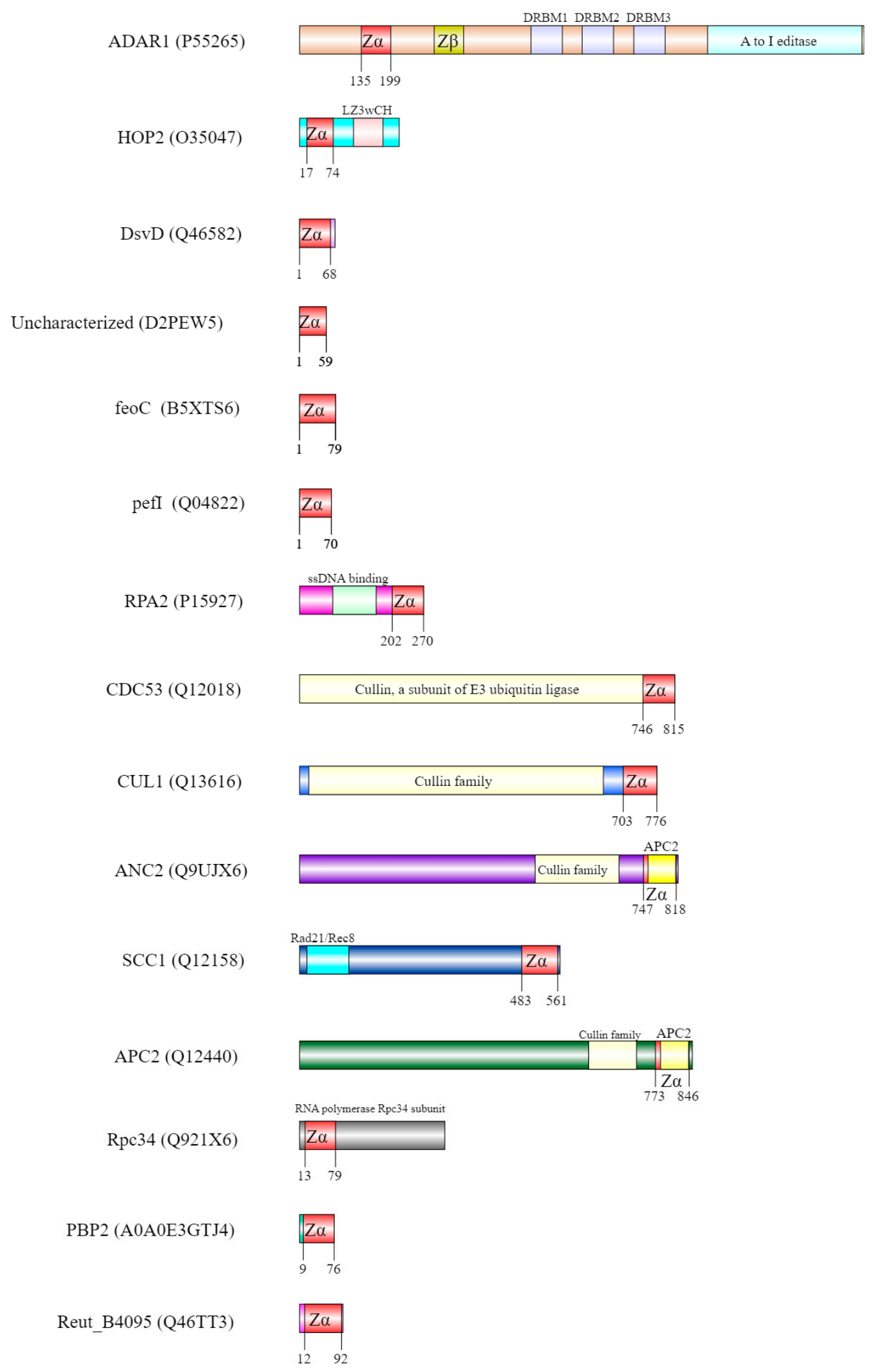

Figure 4. Position of $\mathrm{Z} \alpha$ domain in ADAR1 and within 14 newly described possible Z-DNA/ZRNA binding proteins. The exact position of $Z \alpha$ and its structural homologs is always highlighted in yellow. 


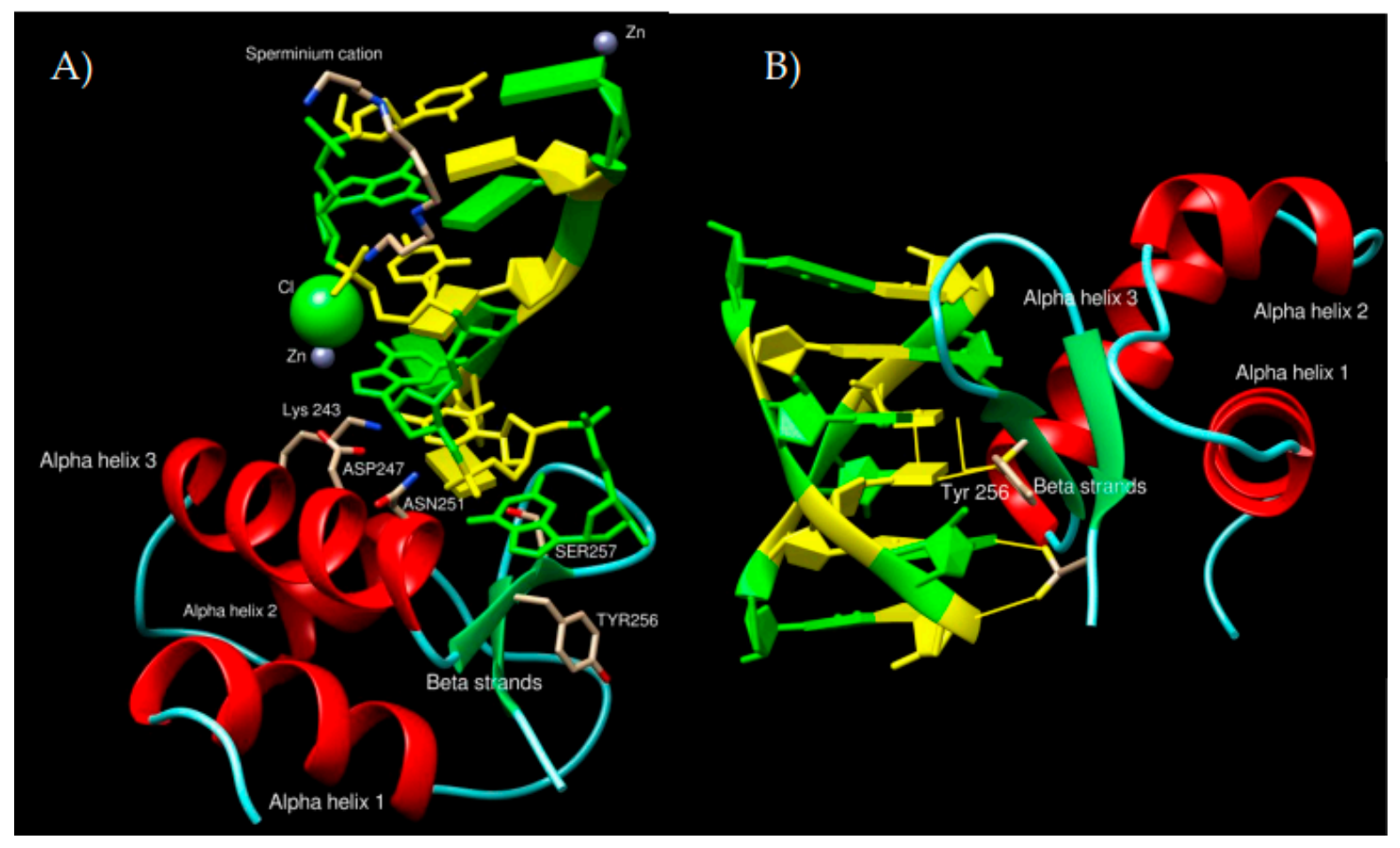

Figure 5. Representative molecular docking of human RPA2 Z $\alpha$ structural homolog to Z-DNA (A) and Z-RNA (B). Protein alpha helices are in red, beta-strands in green, coiled-coil regions in azure. Highlighting of Z-DNA/Z-RNA follows classic NDB colouring (guanines in green, cytosines in yellow).

\subsection{Functional Enrichment and Interaction Network of Human Z-DNA/Z-RNA Binding Proteins}

Finally, we aimed to better illustrate the possible functional interconnection between previously known human proteins ADAR and ZBP1, together with newly predicted human Z-DNA/Z-RNA binding proteins. We have constructed a STRING interaction network [103] made from two previously known human Z-DNA/Z-RNA binding proteins and five newly identified possible human Z-DNA/Z-RNA binding proteins containing structural similarity to the $Z \alpha$ domain. Additionally, the 50 closest interacting proteins were added via STRING (first shell of interactors) to better show possible pathways involving Z-DNA/Z-RNA binding and vice versa (Figure 6). This analysis has shown that newly identified possible Z-DNA/Z-RNA proteins (in humans) are quite distinct from two previously known human Z-DNA/Z-RNA interacting proteins ADAR and ZBP1 (blue cluster). Specifically, proteins RPA2 and HOP2 (syn. PSMC3IP) are both important members of the Meiotic Strand Invasion curated pathway [104] (azure cluster). POLR3F, the human homolog of mouse Rpc34, is interacting mainly with other subunits of RNA polymerase III complex, which is composed of 17 subunits and its structure was solved last year [105]. Interestingly, causative polymerase III mutations have been described in patients with hypersensitivity to viral infection [106,107]. The cluster containing human Cullin 1 protein (yellow) and a cluster containing ANAPC2 protein (red) are very tightly interconnected through functional interactions and involved in various cell cycle processes, including the proteasome-mediated ubiquitin-dependent protein catabolic process, the anaphase-promoting complex-dependent catabolic process, or activation of the innate immune response [108]. These results (Figure 6) reflect the current state of knowledge and do not consider the putative Z-DNA/Z-RNA binding function of proteins POLR3F, RPA2, HOP2/PSMC3IP, CUL1 and ANAPC2, which was first proposed in this manuscript. Once these proteins are validated as bona fide Z-DNA/Z-RNA binding in vitro (and their annotations are actualised within the STRING database), they will probably form a strong functional network by themselves (based on their Z-DNA/Z-RNA annotations). 


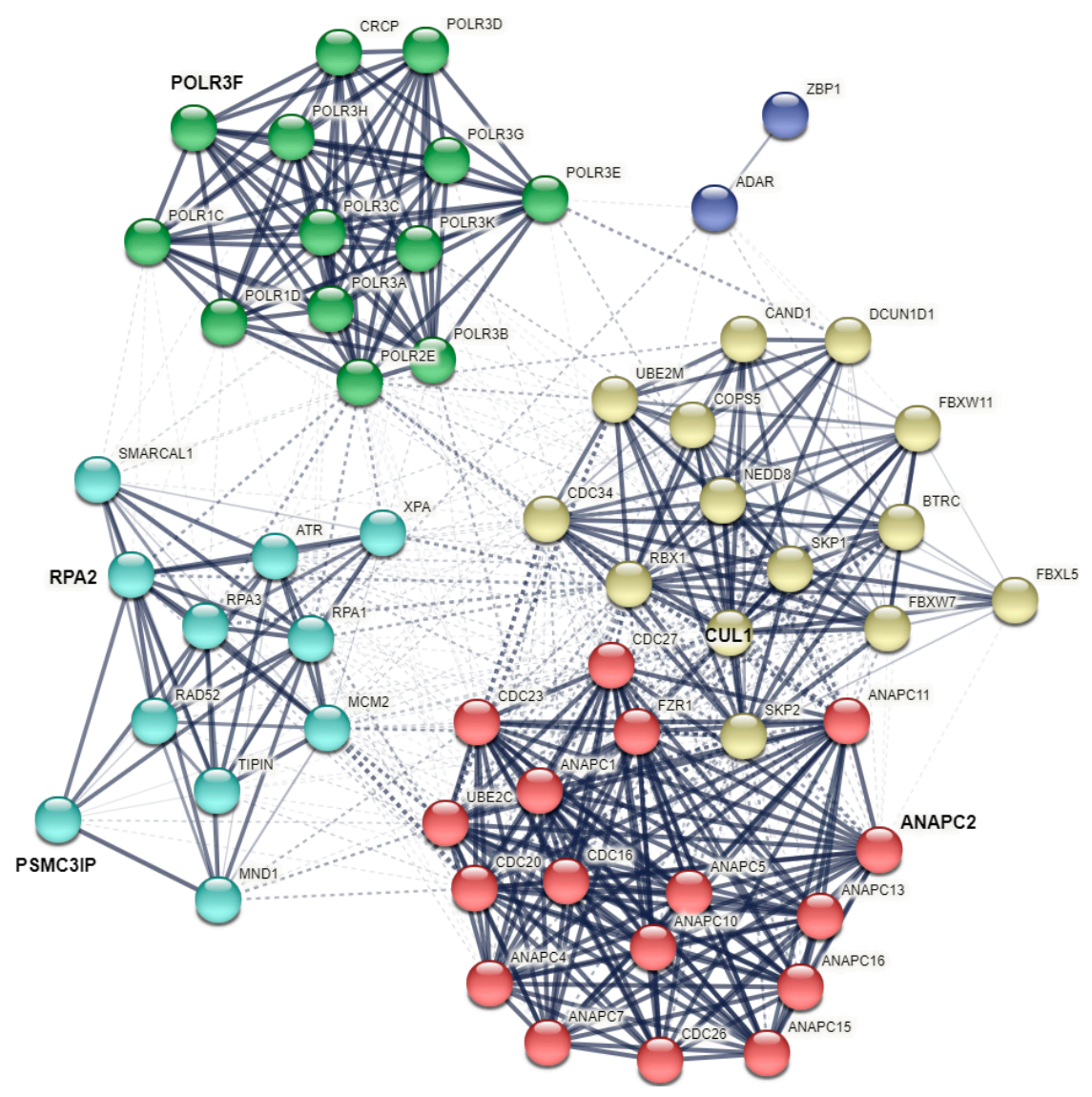

Figure 6. STRING interaction network of newly identified human possible Z-DNA/Z-RNA binding proteins (in bold and higher letter size), together with 2 previously known human Z-DNA/Z-RNA binding proteins (ZBP1 and ADAR), and also with 50 first shell interactors. Clustering was made using MCL inflation parameter (3), the resulting five clusters are highlighted in distinct colours. Line thickness indicates the strength of data support and edges between different clusters are dotted.

\section{Materials and Methods}

\subsection{Collection of Experimentally-Validated Z-DNA/RNA Binding Protein Structures}

A systematic review of existing literature sources deposited in the Web of Science (https:/ / clarivate.com/webofsciencegroup/solutions/web-of-science/, (accessed on 18 August 2021)), NCBI PubMed (https:/ / pubmed.ncbi.nlm.nih.gov/, (accessed on 18 August 2021)), or Google Scholar (https: / /scholar.google.com/, (accessed on 18 August 2021)) databases was done to identify all up-to-date known Z-DNA/RNA binding proteins containing at least one $Z \alpha$ or $Z \beta$ domain. The resulting list of these proteins can be found in Table 1 . Where available, the information about experimentally solved 3D structures was gathered as well.

\subsection{Structure-Based Similarity Searches}

Structure-based similarity searches were performed using the PDBeFold and RUPEE web servers [64], accessed from https:/ /www.ebi.ac.uk/msd-srv/ssm/cgi-bin/ssmserver, (accessed on 10 September 2021), and from https://ayoubresearch.com/, (accessed on 21 October 2021). As a query, the experimentally-resolved structure of the $Z \alpha$ domain was used (PDB: 3f21, chain:A). PDBeFold was used to structurally compare the query Z $\alpha$ domain to all known experimentally-resolved structures in PDB, and RUPEE was used to query against all AlphaFold2 models. Parameters were left to be Default using PDBeFold, except for the "precision", which was changed from "normal" to "high". Three settings were used for the RUPEE search: "Full-Length" (finding exact length matches of the query protein in the database protein), "Contains" (finding query protein inside database protein), and "Contained-In" options (small protein motif detection in query protein). The hits 
resulting from the "Full-Length", "Contained-In", and "Contains" modes using RUPEE were combined to identify the total list of putative unique proteins.

\subsection{Structure Visualisation and Contacts/Clashes Depicting}

All protein structures were visualised and graphically pre-processed in a standalone version of the UCSF Chimera Tool [109]. Prediction of contact amino acid residues was carried out using the Chimera function "Find clashes/contacts" with the following parameters: "VDW overlap" $\geq 0.4$ angstroms; "subtractions of 0.4 from overlap for potentially H-bonding pairs"; "Ignoring contacts of pairs 2 or fewer bonds apart".

\subsection{Structural Alignment Construction}

Structural alignments of newly described Z-DNA/RNA binding proteins were done using Chimera structural analyses toolbox [110], particularly MatchMaker program was used with the following parameters: "Reference structure": 3f21; "Structures to match": 14 newly predicted proteins; "Chain pairing": Best aligning pair of chains between reference and match structures; "Alignment algorithm": Needleman-Wunsch; "Matrix": BLOSUM-62; "Gap opening penalty": 12; "Gap extension penalty": 1; "Include secondary structure score": 50\%; "Compute secondary structure assignments": yes; "Iterate by pruning long atom pairs until no pair exceeds": 2.0 angstroms; "After superposition, compute structure-based multiple sequence alignment": yes; "Create alignment from superposition": choose all 15 protein structures; "Residue-residue distance cutoff": 5.0 angstroms; "Residue aligned in column if within cutoff of": at least one other; "Allow for circular permutation": no; "Iterate superposition/alignment": no.

\subsection{Docking to Z-DNA/RNA}

Docking of the putative RPA2 Z $\alpha$ domain (PDB: 4ou0:A) to Z-DNA (PDB: 4HIF) [111] and Z-RNA (PDB: 1T4X) [112] was done using HDOCK webserver (http: / / hdock.phys.hust. edu.cn/, (accessed on 30 December 2021)) [100] with default parameters. Protein structures were always submitted as a "receptor", and Z-DNA structure as a "ligand". The same procedure was repeated for the rest of the 14 possible Z-DNA/Z-RNA binding proteins. The resulting docking poses (best 10) are enclosed in Supplementary Material S4. The resulting models are sorted according to their HDOCK docking energy scores ("model 1" has the best energy score). Finally, the docking results were manually validated with respect to the existing literature, where main contact residues were determined (see Section 2.3 in Results and Discussion section).

\subsection{Functional Enrichment Analysis}

Functional enrichment analysis of 14 predicted Z-DNA/RNA binding proteins was done as follows: at first, homologous proteins were found in Homo sapiens, where available, and structural conservation of desired " $\mathrm{Z} \alpha$-like" fold was visually checked using AlphaFold prediction [59]. Secondly, five human proteins with conserved "Z $\alpha$-like" fold (identified in this study) were uploaded to STRING webserver together with previously known Z-DNA/RNA binding proteins (https://string-db.org/cgi/input?sessionId= bVBUeCTKWYuE\&input_page_show_search=on, (accessed on 12 December 2021)) [103] and 50 closest interacting proteins were automatically added via STRING (first shell of interactors).

\section{Conclusions}

Our analysis detected the $Z \alpha$ domain structural homologs in fourteen proteins that have not yet been described as Z-DNA/Z-RNA recognising proteins. These suggest that ZDNA/Z-RNA recognition is more common and important in living systems than previously thought. Functional pathways interactions of the newly characterised proteins with a $\mathrm{Z} \alpha$ domain indicate their involvement in innate immunity and other important molecular and biological pathways. These results also highlight the utility of structure-based similarity 
searches to elucidate the structure-function relationship of uncharacterised proteins or protein domains. Further experimental validation is required to determine the extent to which these proteins may bind to Z-DNA/Z-RNA.

Supplementary Materials: The following supporting information can be downloaded at: https:/ / www.mdpi.com/article/10.3390/ijms23020768/s1, S1: RUPEE search through the whole AlphaFold database for proteins containing structural similarity to Z $\alpha$ domain; S2: AlphaFold structures of predicted human Z-DNA/Z-RNA proteins with highlighted Z $\alpha$ domains; S3: Nuclear localisation signals in newly described Z-DNA/Z-RNA binding proteins; S4: Top 10 docking poses for all possible Z-DNA/Z-RNA proteins and selected Z-DNA (PDB: 4HIF) and Z-RNA (PDB: 4HIF) structures.

Author Contributions: Conceptualisation, M.B. and P.P.; data curation, K.S.; formal analysis, M.B. and C.A.B.; methodology, M.B. and C.A.B.; resources, K.S. and M.B.; writing-original draft preparation, M.B., V.B. and K.S.; writing-review and editing, V.B., C.A.B. and J.Č.; visualisation, M.B.; supervision, P.P. and T.L.B. All authors have read and agreed to the published version of the manuscript.

Funding: This research was funded by the Czech Science Foundation, grant number 22-21903S. T.L.B. thanks the Wellcome Trust for support through an Investigator Award (200814/Z/16/Z; 2016-2021). C.A.B. was supported by Antibiotic Research UK (PHZJ/687).

Institutional Review Board Statement: Not applicable.

Informed Consent Statement: Not applicable.

Data Availability Statement: All data is contained within this article or Supplementary Material.

Acknowledgments: We would like to show our gratitude to Adriana Volná (University of Ostrava) for sharing their pearls of wisdom with us during the course of this research.

Conflicts of Interest: The authors declare no conflict of interest. The funders had no role in the design of the study; in the collection, analyses, or interpretation of data; in the writing of the manuscript, or in the decision to publish the results.

\section{References}

1. Guiblet, W.M.; Cremona, M.A.; Harris, R.S.; Chen, D.; Eckert, K.A.; Chiaromonte, F.; Huang, Y.-F.; Makova, K.D. Non-B DNA: A Major Contributor to Small- and Large-Scale Variation in Nucleotide Substitution Frequencies across the Genome. Nucleic Acids Res. 2021, 49, 1497-1516. [CrossRef]

2. Brázda, V.; Bartas, M.; Bowater, R.P. Evolution of Diverse Strategies for Promoter Regulation. Trends Genet. 2021, 37, 730-744. [CrossRef]

3. Lyons, S.M.; Kharel, P.; Akiyama, Y.; Ojha, S.; Dave, D.; Tsvetkov, V.; Merrick, W.; Ivanov, P.; Anderson, P. EIF4G Has Intrinsic G-Quadruplex Binding Activity That Is Required for TiRNA Function. Nucleic Acids Res. 2020, 48, 6223-6233. [CrossRef] [PubMed]

4. Mukherjee, A.K.; Sharma, S.; Chowdhury, S. Non-Duplex G-Quadruplex Structures Emerge as Mediators of Epigenetic Modifications. Trends Genet. 2019, 35, 129-144. [CrossRef]

5. Hayward, B.E.; Usdin, K. Mechanisms of Genome Instability in the Fragile X-Related Disorders. Genes 2021, 12, 1633. [CrossRef]

6. Schaich, M.A.; Van Houten, B. Searching for DNA Damage: Insights from Single Molecule Analysis. Front. Mol. Biosci. 2021, 8, 772877. [CrossRef] [PubMed]

7. Brázda, V.; Laister, R.C.; Jagelská, E.B.; Arrowsmith, C. Cruciform Structures Are a Common DNA Feature Important for Regulating Biological Processes. BMC Mol. Biol. 2011, 12, 33. [CrossRef]

8. Zhao, J.; Bacolla, A.; Wang, G.; Vasquez, K.M. Non-B DNA Structure-Induced Genetic Instability and Evolution. Cell. Mol. Life Sci. 2010, 67, 43-62. [CrossRef]

9. Herbert, A. Z-DNA and Z-RNA in Human Disease. Commun. Biol. 2019, 2, 7. [CrossRef]

10. Roy, R.; Chakraborty, P.; Chatterjee, A.; Sarkar, J. Comparative Review on Left-Handed Z-DNA. Front. Biosci. $2021,26,29-35$.

11. Rajeswari, M.R. DNA Triplex Structures in Neurodegenerative Disorder, Friedreich's Ataxia. J. Biosci. 2012, 37, 519-532. [CrossRef]

12. Varshney, D.; Spiegel, J.; Zyner, K.; Tannahill, D.; Balasubramanian, S. The Regulation and Functions of DNA and RNA G-Quadruplexes. Nat. Rev. Mol. Cell Biol. 2020, 21, 459-474. [CrossRef]

13. Brázda, V.; Hároníková, L.; Liao, J.C.; Fojta, M. DNA and RNA Quadruplex-Binding Proteins. Int. J. Mol. Sci. 2014, 15, 17493-17517. [CrossRef] [PubMed]

14. Brázda, V.; Coufal, J.; Liao, J.C.C.; Arrowsmith, C.H. Preferential Binding of IFI16 Protein to Cruciform Structure and Superhelical DNA. Biochem. Biophys. Res. Commun. 2012, 422, 716-720. [CrossRef] 
15. Schwartz, T.; Rould, M.A.; Lowenhaupt, K.; Herbert, A.; Rich, A. Crystal Structure of the Zalpha Domain of the Human Editing Enzyme ADAR1 Bound to Left-Handed Z-DNA. Science 1999, 284, 1841-1845. [CrossRef]

16. Placido, D.; Brown, B.A.; Lowenhaupt, K.; Rich, A.; Athanasiadis, A. A Left-Handed RNA Double Helix Bound by the Z $\alpha$ Domain of the RNA-Editing Enzyme ADAR1. Structure 2007, 15, 395-404. [CrossRef] [PubMed]

17. Ha, S.C.; Kim, D.; Hwang, H.-Y.; Rich, A.; Kim, Y.-G.; Kim, K.K. The Crystal Structure of the Second Z-DNA Binding Domain of Human DAI (ZBP1) in Complex with Z-DNA Reveals an Unusual Binding Mode to Z-DNA. Proc. Natl. Acad. Sci. USA 2008, 105, 20671-20676. [CrossRef] [PubMed]

18. Schwartz, T.; Behlke, J.; Lowenhaupt, K.; Heinemann, U.; Rich, A. Structure of the DLM-1-Z-DNA Complex Reveals a Conserved Family of Z-DNA-Binding Proteins. Nat. Struct. Mol. Biol. 2001, 8, 761-765. [CrossRef]

19. Kim, D.; Hur, J.; Park, K.; Bae, S.; Shin, D.; Ha, S.C.; Hwang, H.-Y.; Hohng, S.; Lee, J.-H.; Lee, S.; et al. Distinct Z-DNA Binding Mode of a PKR-like Protein Kinase Containing a Z-DNA Binding Domain (PKZ). Nucleic Acids Res. 2014, 42, 5937-5948. [CrossRef]

20. de Rosa, M.; Zacarias, S.; Athanasiadis, A. Structural Basis for Z-DNA Binding and Stabilization by the Zebrafish Z-DNA Dependent Protein Kinase PKZ. Nucleic Acids Res. 2013, 41, 9924-9933. [CrossRef]

21. Kuś, K.; Rakus, K.; Boutier, M.; Tsigkri, T.; Gabriel, L.; Vanderplasschen, A.; Athanasiadis, A. The Structure of the Cyprinid Herpesvirus 3 ORF112-Z $\alpha \cdot Z$-DNA Complex Reveals a Mechanism of Nucleic Acids Recognition Conserved with E3L, a Poxvirus Inhibitor of Interferon Response. J. Biol. Chem. 2015, 290, 30713-30725. [CrossRef]

22. Ha, S.C.; Lokanath, N.K.; Van Quyen, D.; Wu, C.A.; Lowenhaupt, K.; Rich, A.; Kim, Y.-G.; Kim, K.K. A Poxvirus Protein Forms a Complex with Left-Handed Z-DNA: Crystal Structure of a Yatapoxvirus Z $\alpha$ Bound to DNA. Proc. Natl. Acad. Sci. USA 2004, 101, 14367-14372. [CrossRef]

23. Nikpour, N.; Salavati, R. The RNA Binding Activity of the First Identified Trypanosome Protein with Z-DNA-Binding Domains. Sci. Rep. 2019, 9, 5904. [CrossRef] [PubMed]

24. Mitsui, Y.; Langridge, R.; Shortle, B.E.; Cantor, C.R.; Grant, R.C.; Kodama, M.; Wells, R.D. Physical and Enzymatic Studies on Poly d(I-C).Poly d(I-C), an Unusual Double-Helical DNA. Nature 1970, 228, 1166-1169. [CrossRef]

25. Wang, A.H.-J.; Quigley, G.J.; Kolpak, F.J.; Crawford, J.L.; van Boom, J.H.; van der Marel, G.; Rich, A. Molecular Structure of a Left-Handed Double Helical DNA Fragment at Atomic Resolution. Nature 1979, 282, 680-686. [CrossRef]

26. Ha, S.C.; Lowenhaupt, K.; Rich, A.; Kim, Y.-G.; Kim, K.K. Crystal Structure of a Junction between B-DNA and Z-DNA Reveals Two Extruded Bases. Nature 2005, 437, 1183-1186. [CrossRef] [PubMed]

27. Zhang, Y.; Cui, Y.; An, R.; Liang, X.; Li, Q.; Wang, H.; Wang, H.; Fan, Y.; Dong, P.; Li, J.; et al. Topologically Constrained Formation of Stable Z-DNA from Normal Sequence under Physiological Conditions. J. Am. Chem. Soc. 2019, 141, 7758-7764. [CrossRef] [PubMed]

28. Renčiuk, D.; Kypr, J.; Vorlíčková, M. CGG Repeats Associated with Fragile X Chromosome Form Left-Handed Z-DNA Structure. Biopolymers 2011, 95, 174-181. [CrossRef]

29. Bae, S.; Kim, D.; Kim, K.K.; Kim, Y.-G.; Hohng, S. Intrinsic Z-DNA Is Stabilized by the Conformational Selection Mechanism of Z-DNA-Binding Proteins. J. Am. Chem. Soc. 2011, 133, 668-671. [CrossRef]

30. Dumat, B.; Larsen, A.F.; Wilhelmsson, L.M. Studying Z-DNA and B- to Z-DNA Transitions Using a Cytosine Analogue FRET-Pair. Nucleic Acids Res. 2016, 44, e101. [CrossRef]

31. Beknazarov, N.; Jin, S.; Poptsova, M. Deep Learning Approach for Predicting Functional Z-DNA Regions Using Omics Data. Sci. Rep. 2020, 10, 19134. [CrossRef]

32. Champ, P.C.; Maurice, S.; Vargason, J.M.; Camp, T.; Ho, P.S. Distributions of Z-DNA and Nuclear Factor I in Human Chromosome 22: A Model for Coupled Transcriptional Regulation. Nucleic Acids Res. 2004, 32, 6501-6510. [CrossRef]

33. Ho, P.S.; Mooers, B.H. Z-DNA Crystallography. Biopolymers 1997, 14, 65-90. [CrossRef]

34. Herbert, A. ALU Non-B-DNA Conformations, Flipons, Binary Codes and Evolution. R. Soc. Open Sci. 2020, 7, 200222. [CrossRef] [PubMed]

35. Fleming, A.M.; Zhu, J.; Ding, Y.; Esders, S.; Burrows, C.J. Oxidative Modification of Guanine in a Potential Z-DNA-Forming Sequence of a Gene Promoter Impacts Gene Expression. Chem. Res. Toxicol. 2019, 32, 899-909. [CrossRef] [PubMed]

36. Li, H.; Xiao, J.; Li, J.; Lu, L.; Feng, S.; Dröge, P. Human Genomic Z-DNA Segments Probed by the Z $\alpha$ Domain of ADAR1. Nucleic Acids Res. 2009, 37, 2737-2746. [CrossRef]

37. Shin, S.-I.; Ham, S.; Park, J.; Seo, S.H.; Lim, C.H.; Jeon, H.; Huh, J.; Roh, T.-Y. Z-DNA-Forming Sites Identified by ChIP-Seq Are Associated with Actively Transcribed Regions in the Human Genome. DNA Res. 2016, 23, 477-486. [CrossRef] [PubMed]

38. Fogg, J.M.; Randall, G.L.; Pettitt, B.M.; Sumners, D.W.L.; Harris, S.A.; Zechiedrich, L. Bullied No More: When and How DNA Shoves Proteins Around. Q. Rev. Biophys. 2012, 45, 257-299. [CrossRef]

39. Hall, K.; Cruz, P.; Tinoco, I.; Jovin, T.M.; van de Sande, J.H. 'Z-RNA'-A Left-Handed RNA Double Helix. Nature 1984, 311, 584-586. [CrossRef]

40. Zhang, T.; Yin, C.; Boyd, D.F.; Quarato, G.; Ingram, J.P.; Shubina, M.; Ragan, K.B.; Ishizuka, T.; Crawford, J.C.; Tummers, B.; et al. Influenza Virus Z-RNAs Induce ZBP1-Mediated Necroptosis. Cell 2020, 180, 1115-1129.e13. [CrossRef]

41. Cer, R.Z.; Donohue, D.E.; Mudunuri, U.S.; Temiz, N.A.; Loss, M.A.; Starner, N.J.; Halusa, G.N.; Volfovsky, N.; Yi, M.; Luke, B.T.; et al. Non-B DB v2.0: A Database of Predicted Non-B DNA-Forming Motifs and Its Associated Tools. Nucleic Acids Res. 2013, 41, D94-D100. [CrossRef] 
42. Herbert, A.; Lowenhaupt, K.; Spitzner, J.; Rich, A. Double-Stranded RNA Adenosine Deaminase Binds Z-DNA in Vitro. Nucleic Acids Symp. Ser. 1995, 33, 16-19.

43. Chiang, D.C.; Li, Y.; Ng, S.K. The Role of the Z-DNA Binding Domain in Innate Immunity and Stress Granules. Front. Immunol. 2021, 11, 3779. [CrossRef]

44. Lee, A.-R.; Kim, N.-H.; Seo, Y.-J.; Choi, S.-R.; Lee, J.-H. Thermodynamic Model for B-Z Transition of DNA Induced by Z-DNA Binding Proteins. Molecules 2018, 23, 2748. [CrossRef]

45. Wang, H.; Wang, G.; Zhang, L.; Zhang, J.; Zhang, J.; Wang, Q.; Billiar, T.R. ADAR1 Suppresses the Activation of Cytosolic RNA-Sensing Signaling Pathways to Protect the Liver from Ischemia/Reperfusion Injury. Sci. Rep. 2016, 6, 20248. [CrossRef]

46. Takaoka, A.; Wang, Z.; Choi, M.K.; Yanai, H.; Negishi, H.; Ban, T.; Lu, Y.; Miyagishi, M.; Kodama, T.; Honda, K.; et al. DAI (DLM-1/ZBP1) Is a Cytosolic DNA Sensor and an Activator of Innate Immune Response. Nature 2007, 448, 501-505. [CrossRef]

47. Kuriakose, T.; Kanneganti, T.-D. ZBP1: Innate Sensor Regulating Cell Death and Inflammation. Trends Immunol. 2018, 39, 123-134. [CrossRef] [PubMed]

48. Fischer, S.E.J.; Ruvkun, G. Caenorhabditis Elegans ADAR Editing and the ERI-6/7/MOV10 RNAi Pathway Silence Endogenous Viral Elements and LTR Retrotransposons. Proc. Natl. Acad. Sci. USA 2020, 117, 5987-5996. [CrossRef] [PubMed]

49. Kahmann, J.D.; Wecking, D.A.; Putter, V.; Lowenhaupt, K.; Kim, Y.-G.; Schmieder, P.; Oschkinat, H.; Rich, A.; Schade, M. The Solution Structure of the N-Terminal Domain of E3L Shows a Tyrosine Conformation That May Explain Its Reduced Affinity to Z-DNA in Vitro. Proc. Natl. Acad. Sci. USA 2004, 101, 2712-2717. [CrossRef] [PubMed]

50. Thakur, M.; Seo, E.J.; Dever, T.E. Variola Virus E3L Z $\alpha$ Domain, but Not Its Z-DNA Binding Activity, Is Required for PKR Inhibition. RNA 2014, 20, 214-227. [CrossRef]

51. Kim, Y.-G.; Muralinath, M.; Brandt, T.; Pearcy, M.; Hauns, K.; Lowenhaupt, K.; Jacobs, B.L.; Rich, A. A Role for Z-DNA Binding in Vaccinia Virus Pathogenesis. Proc. Natl. Acad. Sci. USA 2003, 100, 6974-6979. [CrossRef]

52. Deigendesch, N.; Koch-Nolte, F.; Rothenburg, S. ZBP1 Subcellular Localization and Association with Stress Granules Is Controlled by Its Z-DNA Binding Domains. Nucleic Acids Res. 2006, 34, 5007-5020. [CrossRef] [PubMed]

53. Ng, S.K.; Weissbach, R.; Ronson, G.E.; Scadden, A.D.J. Proteins That Contain a Functional Z-DNA-Binding Domain Localize to Cytoplasmic Stress Granules. Nucleic Acids Res. 2013, 41, 9786-9799. [CrossRef] [PubMed]

54. Taghavi, N.; Samuel, C.E. RNA-Dependent Protein Kinase PKR and the Z-DNA Binding Orthologue PKZ Differ in Their Capacity to Mediate Initiation Factor EIF2 $\alpha$-Dependent Inhibition of Protein Synthesis and Virus-Induced Stress Granule Formation. Virology 2013, 443, 48-58. [CrossRef]

55. Licht, K.; Jantsch, M.F. The Other Face of an Editor: ADAR1 Functions in Editing-Independent Ways. Bioessays 2017, $39,1700129$. [CrossRef]

56. Herbert, A.; Schade, M.; Lowenhaupt, K.; Alfken, J.; Schwartz, T.; Shlyakhtenko, L.S.; Lyubchenko, Y.L.; Rich, A. The Z $\alpha$ Domain from Human ADAR1 Binds to the Z-DNA Conformer of Many Different Sequences. Nucleic Acids Res. 1998, 26, $3486-3493$. [CrossRef]

57. Kim, U.; Wang, Y.; Sanford, T.; Zeng, Y.; Nishikura, K. Molecular Cloning of CDNA for Double-Stranded RNA Adenosine Deaminase, a Candidate Enzyme for Nuclear RNA Editing. Proc. Natl. Acad. Sci. USA 1994, 91, 11457-11461. [CrossRef] [PubMed]

58. Ha, S.C.; Choi, J.; Hwang, H.-Y.; Rich, A.; Kim, Y.-G.; Kim, K.K. The Structures of Non-CG-Repeat Z-DNAs Co-Crystallized with the Z-DNA-Binding Domain, HZ $\alpha$ ADAR1. Nucleic Acids Res. 2009, 37, 629-637. [CrossRef]

59. Jumper, J.; Evans, R.; Pritzel, A.; Green, T.; Figurnov, M.; Ronneberger, O.; Tunyasuvunakool, K.; Bates, R.; Žídek, A.; Potapenko, A.; et al. Highly Accurate Protein Structure Prediction with AlphaFold. Nature 2021, 596, 583-589. [CrossRef]

60. Athanasiadis, A.; Placido, D.; Maas, S.; Brown, B.A.; Lowenhaupt, K.; Rich, A. The Crystal Structure of the Z $\beta$ Domain of the RNA-Editing Enzyme ADAR1 Reveals Distinct Conserved Surfaces among Z-Domains. J. Mol. Biol. 2005, 351, 496-507. [CrossRef]

61. Schade, M.; Turner, C.J.; Kühne, R.; Schmieder, P.; Lowenhaupt, K.; Herbert, A.; Rich, A.; Oschkinat, H. The Solution Structure of the $\mathrm{Z} \alpha$ Domain of the Human RNA Editing Enzyme ADAR1 Reveals a Prepositioned Binding Surface for Z-DNA. Proc. Natl. Acad. Sci. USA 1999, 96, 12465-12470. [CrossRef] [PubMed]

62. Kim, K.; Khayrutdinov, B.I.; Lee, C.-K.; Cheong, H.-K.; Kang, S.W.; Park, H.; Lee, S.; Kim, Y.-G.; Jee, J.; Rich, A.; et al. Solution Structure of the $\mathrm{Z} \beta$ Domain of Human DNA-Dependent Activator of IFN-Regulatory Factors and Its Binding Modes to B- and Z-DNAs. Proc. Natl. Acad. Sci. USA 2011, 108, 6921-6926. [CrossRef]

63. Park, C.; Zheng, X.; Park, C.Y.; Kim, J.; Lee, S.K.; Won, H.; Choi, J.; Kim, Y.-G.; Choi, H.-J. Dual Conformational Recognition by Z-DNA Binding Protein Is Important for the B-Z Transition Process. Nucleic Acids Res. 2020, 48, 12957-12971. [CrossRef] [PubMed]

64. Krissinel, E.; Henrick, K. Secondary-Structure Matching (SSM), a New Tool for Fast Protein Structure Alignment in Three Dimensions. Acta Cryst. D Biol. Cryst. 2004, 60, 2256-2268. [CrossRef]

65. Leu, J.Y.; Chua, P.R.; Roeder, G.S. The Meiosis-Specific Hop2 Protein of S. Cerevisiae Ensures Synapsis between Homologous Chromosomes. Cell 1998, 94, 375-386. [CrossRef]

66. Chan, Y.-L.; Brown, M.S.; Qin, D.; Handa, N.; Bishop, D.K. The Third Exon of the Budding Yeast Meiotic Recombination Gene HOP2 Is Required for Calcium-Dependent and Recombinase Dmc1-Specific Stimulation of Homologous Strand Assimilation. J. Biol. Chem. 2014, 289, 18076-18086. [CrossRef] 
67. Mizuno, N.; Voordouw, G.; Miki, K.; Sarai, A.; Higuchi, Y. Crystal Structure of Dissimilatory Sulfite Reductase D (DsrD) Protein-Possible Interaction with B- and Z-DNA by Its Winged-Helix Motif. Structure 2003, 11, 1133-1140. [CrossRef]

68. Hung, K.-W.; Tsai, J.-Y.; Juan, T.-H.; Hsu, Y.-L.; Hsiao, C.-D.; Huang, T.-H. Crystal Structure of the Klebsiella Pneumoniae NFeoB/FeoC Complex and Roles of FeoC in Regulation of Fe ${ }^{2+}$ Transport by the Bacterial Feo System. J. Bacteriol. 2012, 194, 6518-6526. [CrossRef]

69. Aramini, J.M.; Rossi, P.; Cort, J.R.; Ma, L.-C.; Xiao, R.; Acton, T.B.; Montelione, G.T. Solution NMR Structure of the PlasmidEncoded Fimbriae Regulatory Protein PefI from Salmonella Enterica Serovar Typhimurium. Proteins Struct. Funct. Bioinform. 2011, 79, 335-339. [CrossRef]

70. Sleeth, K.M.; Sørensen, C.S.; Issaeva, N.; Dziegielewski, J.; Bartek, J.; Helleday, T. RPA Mediates Recombination Repair during Replication Stress and Is Displaced from DNA by Checkpoint Signalling in Human Cells. J. Mol. Biol. 2007, 373, 38-47. [CrossRef] [PubMed]

71. Grudic, A.; Jul-Larsen, A.; Haring, S.J.; Wold, M.S.; Lønning, P.E.; Bjerkvig, R.; Bøe, S.O. Replication Protein A Prevents Accumulation of Single-Stranded Telomeric DNA in Cells That Use Alternative Lengthening of Telomeres. Nucleic Acids Res. 2007, 35, 7267-7278. [CrossRef]

72. Erdile, L.F.; Wold, M.S.; Kelly, T.J. The Primary Structure of the 32-KDa Subunit of Human Replication Protein A. J. Biol. Chem. 1990, 265, 3177-3182. [CrossRef]

73. Maestroni, L.; Audry, J.; Luciano, P.; Coulon, S.; Géli, V.; Corda, Y. RPA and Pif1 Cooperate to Remove G-Rich Structures at Both Leading and Lagging Strand. Cell Stress 2020, 4, 48-63. [CrossRef] [PubMed]

74. Seol, J.H.; Feldman, R.M.; Zachariae, W.; Shevchenko, A.; Correll, C.C.; Lyapina, S.; Chi, Y.; Galova, M.; Claypool, J.; Sandmeyer, S.; et al. Cdc53/Cullin and the Essential Hrt1 RING-H2 Subunit of SCF Define a Ubiquitin Ligase Module That Activates the E2 Enzyme Cdc34. Genes Dev. 1999, 13, 1614-1626. [CrossRef]

75. Sweeney, M.A.; Iakova, P.; Maneix, L.; Shih, F.-Y.; Cho, H.E.; Sahin, E.; Catic, A. The Ubiquitin Ligase Cullin-1 Associates with Chromatin and Regulates Transcription of Specific c-MYC Target Genes. Sci. Rep. 2020, 10, 13942. [CrossRef] [PubMed]

76. Barford, D. Structural Interconversions of the Anaphase-Promoting Complex/Cyclosome (APC/C) Regulate Cell Cycle Transitions. Curr. Opin. Struct. Biol. 2020, 61, 86-97. [CrossRef] [PubMed]

77. Skibbens, R.V. Buck the Establishment: Reinventing Sister Chromatid Cohesion. Trends Cell Biol. 2010, 20, 507-513. [CrossRef]

78. Zachariae, W.; Shevchenko, A.; Andrews, P.D.; Ciosk, R.; Galova, M.; Stark, M.J.; Mann, M.; Nasmyth, K. Mass Spectrometric Analysis of the Anaphase-Promoting Complex from Yeast: Identification of a Subunit Related to Cullins. Science 1998, 279, 1216-1219. [CrossRef] [PubMed]

79. Chiu, Y.-H.; MacMillan, J.B.; Chen, Z.J. RNA Polymerase III Detects Cytosolic DNA and Induces Type-I Interferons Through the RIG-I Pathway. Cell 2009, 138, 576-591. [CrossRef]

80. Yan, J.; Beattie, T.R.; Rojas, A.L.; Schermerhorn, K.; Gristwood, T.; Trinidad, J.C.; Albers, S.V.; Roversi, P.; Gardner, A.F.; Abrescia, N.G.A.; et al. Identification and Characterization of a Heterotrimeric Archaeal DNA Polymerase Holoenzyme. Nat. Commun. 2017, 8, 15075. [CrossRef] [PubMed]

81. Enomoto, R.; Kinebuchi, T.; Sato, M.; Yagi, H.; Kurumizaka, H.; Yokoyama, S. Stimulation of DNA Strand Exchange by the Human TBPIP/Hop2-Mnd1 Complex. J. Biol. Chem. 2006, 281, 5575-5581. [CrossRef]

82. Zangen, D.; Kaufman, Y.; Zeligson, S.; Perlberg, S.; Fridman, H.; Kanaan, M.; Abdulhadi-Atwan, M.; Abu Libdeh, A.; Gussow, A.; Kisslov, I.; et al. XX Ovarian Dysgenesis Is Caused by a PSMC3IP/HOP2 Mutation That Abolishes Coactivation of Estrogen-Driven Transcription. Am. J. Hum. Genet. 2011, 89, 572-579. [CrossRef] [PubMed]

83. Rudnicka, A.; Yamauchi, Y. Ubiquitin in Influenza Virus Entry and Innate Immunity. Viruses 2016, 8, 293. [CrossRef]

84. Carter-Timofte, M.E.; Hansen, A.F.; Mardahl, M.; Fribourg, S.; Rapaport, F.; Zhang, S.-Y.; Casanova, J.-L.; Paludan, S.R.; Christiansen, M.; Larsen, C.S.; et al. Varicella-Zoster Virus CNS Vasculitis and RNA Polymerase III Gene Mutation in Identical Twins. Neurol.-Neuroimmunol. Neuroinflamm. 2018, 5, e500. [CrossRef]

85. Van Quyen, D.; Ha, S.C.; Lowenhaupt, K.; Rich, A.; Kim, K.K.; Kim, Y.-G. Characterization of DNA-Binding Activity of Z $\alpha$ Domains from Poxviruses and the Importance of the $\beta$-Wing Regions in Converting B-DNA to Z-DNA. Nucleic Acids Res. 2007, 35, 7714-7720. [CrossRef] [PubMed]

86. Chemes, L.B.; de Prat-Gay, G.; Sánchez, I.E. Convergent Evolution and Mimicry of Protein Linear Motifs in Host-Pathogen Interactions. Curr. Opin. Struct. Biol. 2015, 32, 91-101. [CrossRef]

87. Tomii, K.; Sawada, Y.; Honda, S. Convergent Evolution in Structural Elements of Proteins Investigated Using Cross Profile Analysis. BMC Bioinform. 2012, 13, 11. [CrossRef] [PubMed]

88. Brázda, V.; Červeň, J.; Bartas, M.; Mikysková, N.; Coufal, J.; Pečinka, P. The Amino Acid Composition of Quadruplex Binding Proteins Reveals a Shared Motif and Predicts New Potential Quadruplex Interactors. Molecules 2018, 23, 2341. [CrossRef] [PubMed]

89. Bartas, M.; Bažantová, P.; Brázda, V.; Liao, J.C.; Červeň, J.; Pečinka, P. Identification of Distinct Amino Acid Composition of Human Cruciform Binding Proteins. Mol. Biol. 2019, 53, 97-106. [CrossRef]

90. Sousounis, K.; Haney, C.E.; Cao, J.; Sunchu, B.; Tsonis, P.A. Conservation of the Three-Dimensional Structure in Non-Homologous or Unrelated Proteins. Hum. Genom. 2012, 6, 10. [CrossRef]

91. Zhang, Y.; Skolnick, J. TM-Align: A Protein Structure Alignment Algorithm Based on the TM-Score. Nucleic Acids Res. 2005, 33, 2302-2309. [CrossRef] 
92. Perrakis, A.; Sixma, T.K. AI Revolutions in Biology. EMBO Rep. 2021, 22, e54046. [CrossRef]

93. Uanschou, C.; Ronceret, A.; Von Harder, M.; De Muyt, A.; Vezon, D.; Pereira, L.; Chelysheva, L.; Kobayashi, W.; Kurumizaka, H.; Schlögelhofer, P.; et al. Sufficient Amounts of Functional HOP2/MND1 Complex Promote Interhomolog DNA Repair but Are Dispensable for Intersister DNA Repair during Meiosis in Arabidopsis. Plant Cell 2013, 25, 4924-4940. [CrossRef] [PubMed]

94. Poulsen, H.; Nilsson, J.; Damgaard, C.K.; Egebjerg, J.; Kjems, J. CRM1 Mediates the Export of ADAR1 through a Nuclear Export Signal within the Z-DNA Binding Domain. Mol. Cell. Biol. 2001, 21, 7862-7871. [CrossRef]

95. Strehblow, A.; Hallegger, M.; Jantsch, M.F. Nucleocytoplasmic Distribution of Human RNA-Editing Enzyme ADAR1 Is Modulated by Double-Stranded RNA-Binding Domains, a Leucine-Rich Export Signal, and a Putative Dimerization Domain. Mol. Biol. Cell 2002, 13, 3822-3835. [CrossRef] [PubMed]

96. Kim, C. How Z-DNA/RNA Binding Proteins Shape Homeostasis, Inflammation, and Immunity. BMB Rep. 2020, 53, 453-457. [CrossRef] [PubMed]

97. Gallo, A.; Vukic, D.; Michalík, D.; O'Connell, M.A.; Keegan, L.P. ADAR RNA Editing in Human Disease; More to It than Meets the I. Hum. Genet. 2017, 136, 1265-1278. [CrossRef]

98. Kosugi, S.; Hasebe, M.; Tomita, M.; Yanagawa, H. Systematic Identification of Cell Cycle-Dependent Yeast Nucleocytoplasmic Shuttling Proteins by Prediction of Composite Motifs. Proc. Natl. Acad. Sci. USA 2009, 106, 10171-10176. [CrossRef]

99. Bartas, M.; Červeň, J.; Guziurová, S.; Slychko, K.; Pečinka, P. Amino Acid Composition in Various Types of Nucleic Acid-Binding Proteins. Int. J. Mol. Sci. 2021, 22, 922. [CrossRef]

100. Yan, Y.; Tao, H.; He, J.; Huang, S.-Y. The HDOCK Server for Integrated Protein-Protein Docking. Nat. Protoc. 2020, 15, 1829-1852. [CrossRef]

101. Nichols, P.J.; Bevers, S.; Henen, M.; Kieft, J.S.; Vicens, Q.; Vögeli, B. Recognition of Non-CpG Repeats in Alu and Ribosomal RNAs by the Z-RNA Binding Domain of ADAR1 Induces A-Z Junctions. Nat. Commun. 2021, 12, 793. [CrossRef]

102. Kim, D.; Lee, Y.-H.; Hwang, H.-Y.; Kim, K.K.; Park, H.-J. Z-DNA Binding Proteins as Targets for Structure-Based Virtual Screening. Curr. Drug Targets 2010, 11, 335-344. [CrossRef]

103. Szklarczyk, D.; Gable, A.L.; Lyon, D.; Junge, A.; Wyder, S.; Huerta-Cepas, J.; Simonovic, M.; Doncheva, N.T.; Morris, J.H.; Bork, P.; et al. STRING V11: Protein-Protein Association Networks with Increased Coverage, Supporting Functional Discovery in Genome-Wide Experimental Datasets. Nucleic Acids Res. 2019, 47, D607-D613. [CrossRef]

104. Jassal, B.; Matthews, L.; Viteri, G.; Gong, C.; Lorente, P.; Fabregat, A.; Sidiropoulos, K.; Cook, J.; Gillespie, M.; Haw, R.; et al. The Reactome Pathway Knowledgebase. Nucleic Acids Res. 2020, 48, D498-D503. [CrossRef]

105. Ramsay, E.P.; Abascal-Palacios, G.; Daiß, J.L.; King, H.; Gouge, J.; Pilsl, M.; Beuron, F.; Morris, E.; Gunkel, P.; Engel, C.; et al. Structure of Human RNA Polymerase III. Nat. Commun. 2020, 11, 6409. [CrossRef]

106. Ogunjimi, B.; Zhang, S.-Y.; Sørensen, K.B.; Skipper, K.A.; Carter-Timofte, M.; Kerner, G.; Luecke, S.; Prabakaran, T.; Cai, Y.; Meester, J.; et al. Inborn Errors in RNA Polymerase III Underlie Severe Varicella Zoster Virus Infections. J. Clin. Investig. 2017, 127, 3543-3556. [CrossRef] [PubMed]

107. Carter-Timofte, M.E.; Hansen, A.F.; Christiansen, M.; Paludan, S.R.; Mogensen, T.H. Mutations in RNA Polymerase III Genes and Defective DNA Sensing in Adults with Varicella-Zoster Virus CNS Infection. Genes Immun. 2019, 20, 214-223. [CrossRef]

108. The Gene Ontology Consortium Gene Ontology Consortium: Going Forward. Nucleic Acids Res. 2015, 43, D1049-D1056. [CrossRef]

109. Pettersen, E.F.; Goddard, T.D.; Huang, C.C.; Couch, G.S.; Greenblatt, D.M.; Meng, E.C.; Ferrin, T.E. UCSF Chimera-A Visualization System for Exploratory Research and Analysis. J. Comput. Chem. 2004, 25, 1605-1612. [CrossRef] [PubMed]

110. Meng, E.C.; Pettersen, E.F.; Couch, G.S.; Huang, C.C.; Ferrin, T.E. Tools for Integrated Sequence-Structure Analysis with UCSF Chimera. BMC Bioinform. 2006, 7, 339. [CrossRef] [PubMed]

111. Drozdzal, P.; Gilski, M.; Kierzek, R.; Lomozik, L.; Jaskolski, M. Ultrahigh-Resolution Crystal Structures of Z-DNA in Complex with $\mathrm{Mn}^{2+}$ and $\mathrm{Zn}^{2+}$ Ions. Acta Cryst. D 2013, 69, 1180-1190. [CrossRef] [PubMed]

112. Popenda, M.; Milecki, J.; Adamiak, R.W. High Salt Solution Structure of a Left-Handed RNA Double Helix. Nucleic Acids Res. 2004, 32, 4044-4054. [CrossRef] [PubMed] 